\title{
Ekstraksi dan Karakterisasi Gelatin Tulang Itik Menggunakan Metode Ekstraksi Asam
}

\section{Extraction and Characterization of Duck Bone Gelatin Using Acid Extraction Method}

\author{
M. H. Khirzin, S. Ton dan Fatkhurrohman \\ Program Studi Teknologi Pengolahan Hasil Ternak Politeknik Negeri Banyuwangi \\ Jl. Raya Jember Km. 13, Labanasem, Kabat, Banyuwangi \\ Corresponding e-mail: habbibkhirzin@poliwangi.ac.id
}

\begin{abstract}
The aim of this research was to determine the physicochemical properties of duck bone gelatin which was extracted by using acid method. The experiment was a completely non factorial randomized design (CDR)with three treatments and three replications. The treatment were (P1) with the concentration of $\mathrm{HCl} 2.5 \%$, (P2) with the concentration of $\mathrm{HCl} 5 \%$, and (P3) with the concentration of $\mathrm{HCl} 7.5 \%$. The result showed that yields of each treatment were $4.97 \%, 6.24 \%$, and $6.11 \%$. $\mathrm{pH}$ of gelatin was 4.76, 4.0, and 3.56. Water contents of gelatin in each treatment were $9.01 \%, 13.43 \%$, and $13.84 \%$. Ash contents in each treatment were $27.02 \%, 3.42 \%$, and 20.3\%. Fat contents were $6.5 \%, 6.74 \%$, and $5.77 \%$. Protein contents were $51.67 \%, 65.43 \%$, and $59.05 \%$. While carbohydrate contents were $5.80 \%, 0.98 \%$, and $1.04 \%$ in each treatment.Generally, the difference of acid solution concentration was not significant $(\mathrm{P}>0.05)$ on physicochemical properties of duck bone gelatin except ash content. P2 treatment gave the best physicochemical properties so that its color degree and functional group was analyzed. Color degree assays gave result $\mathrm{L}=30.35$, $\mathrm{a}=-0.46$, dan $\mathrm{b}=3.51$. Functional group analysis showed that duck bone gelatin had chemical shift on Amide A, B, I, II, and III. The conclusion was the extraction of duck bone gelatin by using $5 \%$ acid solution had physicochemical properties which wasappropriate with SNI and similar with commercial gelatin.
\end{abstract}

Key word: Duck bone, acid extraction, gelatin.

\begin{abstract}
ABSTRAK
Tujuan dari penelitian ini adalah untuk mengetahui karakteristik fisikokimia gelatin tulang itik yang diekstrak dengan menggunakan metode asam.Penelitian ini menggunakan rancangan acak lengkap (RAL) sederhana non faktorial dengan 3 perlakuan dan masing-masing perlakuan diulang sebanyak 3 kali. Perlakuan yang digunakan yaitu (P1) dengan konsentrasi $\mathrm{HCl} 2.5 \%$, (P2) dengan konsentrasi $\mathrm{HCl} 5 \%$, dan (P3) dengan konsentrasi $\mathrm{HCl}$ 7.5\%.Hasil penelitian menunjukan bahwa rendemen yang dihasilkan dari setiap perlakuan berturut-turut sebesar 4.97\%, 6.24\%, dan 6.11\%.pHgelatin tulang itik sebesar 4.76, 4.0, dan 3.56. Kadar air sebesar 9.01e\%, $13.43 \%$, dan $13.84 \%$.Kadar abu sebesar $27.02 \%, 13.42 \%$, dan $20.3 \%$.Kadar lemak sebesar $6.5 \%, 6.74 \%$, dan $5.77 \%$. Kadar protein sebesar $51.67 \%$, 65.43\%, dan 59.05\%.Kadar karbohidrat sebesar $5.80 \%$, $0.98 \%$, dan $1.04 \%$.Secara umum, perbedaan konsentrasi larutan asam tidak berpengaruh nyata $(\mathrm{P}>0.05)$ terhadap karakteristik fisikokimia yang dihasilkan kecuali kadar abu. P2 merupakan perlakuan denagan karakteristik fisikokimia terbaik sehingga dianalisis lebih lanjut derajat warna dan gugus fungsional. Uji derajat warna memberikan hasil yaitu $\mathrm{L}=30.35$, $\mathrm{a}=-0.46$, dan $\mathrm{b}=3.51$. Hasil analisis gugus fungsional memberikan hasil gelatin tulang itik memiliki serapan pada wilayah amida A, B, I, II, dan III. Kesimpulan yang dapat diambil adalah ekstraksi gelatin tulang itik menggunakan konsentrasi asam 5\% memiliki karakteristik yang memenuhi SNI dan mirip dengan gelatin komersial.
\end{abstract}

Kata kunci : Tulang itik, ekstraksi asam, gelatin.

\section{PENDAHULUAN}

Gelatin merupakan produk hasil hidrolisis kolagen dari kulit, jaringan ikat dan tulang hewan. Gelatin selama ini dimanfaatkan oleh industri baik pangan maupun non-pangan. Industri pangan memanfaatkan gelatin sebagai bahan tambahan pangan (BTP) seperti pembentuk busa, penstabil, pembentuk gel, perekat, pengental dan pengemulsi (Sari, 2017). Secara umum, gelatin diproduksi dari sumber babi dan sapi. Sumber bahan 
pembuatan gelatin masih menjadi pertimbangan bagi umat muslim karena sebagian produsen menggunakan kulit babi. GMAP (2007) melaporkan bahan baku yang digunakan oleh para produsen gelatin dunia kebanyakan berbahan dasar kulit babi (46\%), kulit sapi (28\%), tulang sapi (24\%), dan bahan lainnya (2\%). Status haram pada produk berbahan dasar babi dan kasus zoonosis sapi gila di negara-negara produsen gelatin seperti Perancis, Jepang, Brazil, Cina, Argentina, dan Australia menjadi hal yang cukup intensif dibicarakan untuk dicari alternatif pengganti sumber gelatin.

Kebutuhan gelatin dari tahun ke tahun terus mengalami peningkatan seiring dengan perkembangan teknologi industri pengolahan pangan.Pencarian sumber gelatin yang baru sebagai alternatif gelatin dari sumber babi dan sapi terus dilakukan dan digali. Beberapa bahan yang bisa dijadikan sebagai sumber gelatin diantaranya unggas, hewan laut, dan serangga (Mariod, 2013). Miskah et al (2010) dan Jannah et al (2013) melaporkan bahwa gelatin yang diekstraksi dari tulang dan kaki unggas maupun ikan memiliki karakteristik yang mirip dengan gelatin babi.Gelatin berdasarkan metode ekstraksinya dibagi menjadi 2 tipe yaitu A dan B.Gelatin tipe A diekstrak menggunakan asam seperti $\mathrm{HCl}, \mathrm{H}_{2} \mathrm{SO}_{4}$ sedangkan tipe $\mathrm{B}$ diekstraksi menggunakan basa seperti $\mathrm{KOH}$ dan $\mathrm{NaOH}$. Ekstraksi asam dinilai lebih efektif dan menghasilkan rendemen lebih tinggi dibandingkan metode basa.

Ketersediaan limbah tulang unggas di Indonesia seperti itik jumlahnya melimpah dan sampai saat ini masih belum dimanfaatkan secara maksimal. Limbah tulang biasanya hanya dihancurkan dan dijadikan campuran pakan hewan. Tulang itik memiliki potensi yang bagus untuk dikembangkan menjadi gelatin sehinga mampu meningkatkan nilai tambah (value added). Eksplorasi sumber gelatin terus dilakukan untuk mencari pengganti gelatin dari sumber babi dan sapi sehingga perlu dilakukan penelitian mengenai kajian potensi tulang itik menjadi sumber gelatin dengan metode ekstraksi asam.

\section{MATERI DAN METODE}

Bahan utama berupa tulang itik didapatkan dari restoran dan rumah makan di Kabupaten Banyuwangi, sedangkan bahan kimia dan bahan analisa didapatkan dari Laboratorium Teknologi Pengolahan Hasil Ternak Politeknik Negeri Banyuwangi. Penelitian ini dilaksanakan pada bulan JuniSeptember 2018. Penelitian dibagi menjadi 3 tahap yaitu pretreatment, ekstraksi, dan analisis.

Tahap pretreatment dilakukan berdasarkan metode Ulfa et al (2015) dengan sedikti modifikasi.Tahapannya yaitu tulang itik dicuci kemudian direndam dalam aquades (1:3) dan dipanaskan pada suhu $80^{\circ}$ Cselama 2 jam.Tahap ini bertujuan untuk menghilangkan sisa kotoran yang masih menempel pada tulang.Selanjutnya dilakukan proses demineralisasi I yaitu tulang dipotong kecil-kecil hingga berukuran 2-3 cm kemudian direndam dalam larutan $\mathrm{NaOH} 1$ M (1:5) selama 2 jam. Setelah selesai, tulang dinetralkan menggunakan aquades kemudian dilanjutkan proses demineralisasi II yaitu tulang direndam dalam larutan $\mathrm{HCl}$ konsentrasi $2.5 \%, 5 \%$, dan $7.5 \%$ selama 24 jam lalu kembali dinetralkan menggunakan aquades hingga terbentuk ossein. Tahap demineralisasi bertujuan untuk menghilangkan kandungan mineral, lemak, dan protein nonkolagen dari tulang itik.

Tahapan ekstraksi dilakukan berdasarkan metode Sirikhwatinrat dan Silaasna (2017) dengan sedikit modifikasi.Proses ekstraksimeliputiossein (tulang lunak) direndam dalam aquades (1:3) kemudian dipanaskan secara bertahap yaitu yang pertama menggunakan suhu $70^{\circ} \mathrm{C}$ selama 1 jam. Setelah selesai, campuran disaring menggunakan kain cheesecloth dan filtrat disimpan didalam freezer. Tahap kedua yaitu tulang kembali direndam dalam aquades (1:3) kemudian dipanaskan suhu $80^{\circ} \mathrm{C}$ selama 1 jam dan filtrat dikumpulkan bersama hasil ekstraksi pertama. Tahapan selanjutnya yaitu gelatin dikeringkan menggunakan oven pengering hingga 
terbentuk gelatin serbuk. Karakteristik fisikokimia yang diujikan pada sampel gelatin meliputi nilai rendemen, $\mathrm{pH}$, kadar air, kadar abu, kadar lemak, kadar protein, kadar karbohidrat, derajat warna, dan gugus fungsional.

Datahasil penelitian dianalisis menggunakan analisis sidik ragam (Analysis of Variance atau ANOVA). Jika terdapat perbedaan yang nyata antara perlakuan maka dilanjutkan dengan uji Duncan multiple range test (Mattjik \& Sumertajaya, 2006).

\section{HASIL DAN PEMBAHASAN}

\section{Ekstraksi Gelatin}

Proses ekstraksi gelatin melalui beberapa tahap danmemerlukan waktu yang lama. Hal ini disebabkan karena gelatin merupakan komponen yang terikat kuat di dalam jaringan tulang sehingga proses ekstraksi memerlukan beberapa tahap pretreatment (praperlakuan). Praperlakuan yang pertama yaitu degreasing untuk memecah komponen mineral dengan suhu tinggi. Setelah degreasing, dilanjutkan tahap defatting dan demineralisasi dengan larutan $\mathrm{NaOH}$ dan $\mathrm{HCl}$ selama beberapa jam untuk menghilangkan komponen lemak, protein non kolagen, dan mineral kalsium.

Faktor-faktor yang mempengaruhi proses ekstraksi gelatin diantaranya tahap pretreatment, jenis, dan usia hewan. Tahap pretreatment yang keliru menyebabkan viskositas dan rendemen gelatin rendah.Usia hewan juga mempengaruhi proses. Semakin tua usia hewan maka tulang akan semakin keras, susah diekstrak, dan gelatin yang dihasilkan lebih gelap.Secara sekilas, gelatin yang diekstrak dari tulang itik memiliki warna dan bentuk yang mirip dengan gelatin komersial. Adapun hasil ekstraksi gelatin tulang itik dapat dilihat pada Gambar 1.

Rendemen gelatin yang diekstrak dari tulang itik dengan konsentrasi $\mathrm{HCl} 2.5 \%$, $5 \%$, dan $7.5 \%$ berturut-turut sebesar $4.95 \%$, $6.24 \%$, dan $6.11 \%$. Perbedaaan konsentrasi $\mathrm{HCl}$ memberikan pengaruh yang tidak beda nyata $(\mathrm{P}>0.05)$ terhadap gelatin yang dihasilkan.

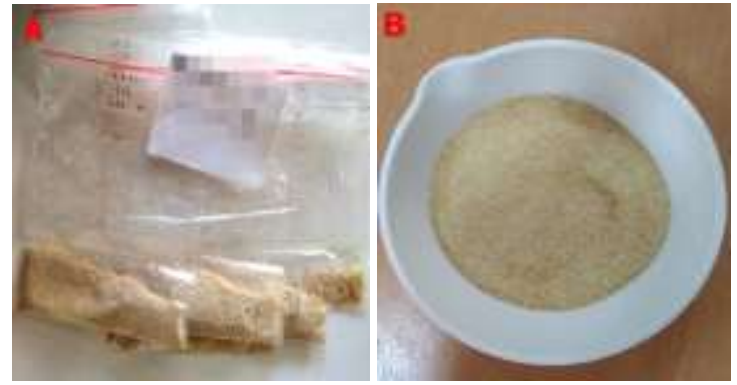

Gambar 1. a). Gelatin tulang itik, b). Gelatin komersial

Nilai rendemen dapat dilihat pada Gambar 2. Rendemen tertinggi terdapat pada perlakuan $\mathrm{HCl} 5 \%$ sebesar $6.24 \%$. Miskah et al (2010) melaporkan tulang ayam broiler yang diekstrak dengan $\mathrm{HCl} 4 \%$ memiliki rendemen sebesar $2.62 \%$. Semakin tinggi konsentrasi $\mathrm{HCl}$ yang digunakan maka rendemen yang dihasilkan semakin turun karena komponen gelatin ikut hancur dan larut di dalam $\mathrm{HCl}$. Konsentrasi $\mathrm{HCl}$ yang terlalu rendah juga menyebabkan rendemen rendah karena gelatin masih terikat kuat pada jaringan tulang sehingga proses ekstraksi kurang efektif. Gelatin merupakan produk hidrolisis parsial kolagen. Salah satu faktor yang mempengaruhi tinggi atau rendahnya rendemen yaitu struktur tulang yang berongga.Rongga tersebut berisi sumsum yang bukan kolagen. Semakin berongga suatu tulang maka semakin rendah rendemen gelatin yang dihasilkan.

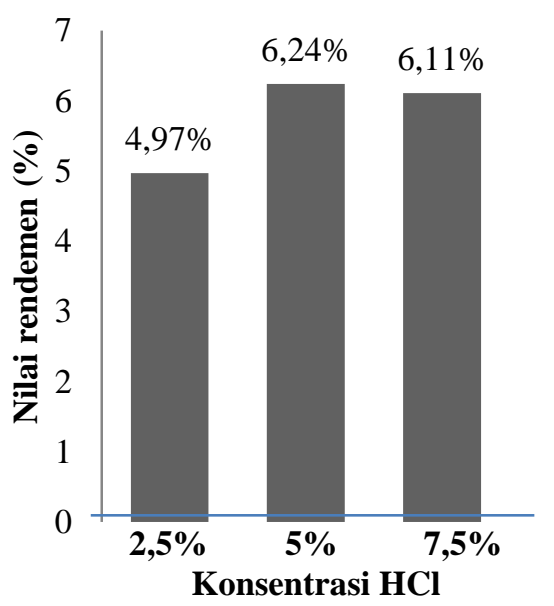

Gambar 2. Nilai rata-rata rendemen (\%) gelatin tulang itik 
Tabel 1. Karakteristik kimiawi gelatin

\begin{tabular}{lcccc}
\hline \multirow{2}{*}{ Parameter } & \multicolumn{2}{c}{ Perlakuan konsentrasi HCl (\%) } & \multirow{2}{*}{ SNI } \\
\cline { 2 - 4 } & $2,5 \%$ & $5 \%$ & $7,5 \%$ & \\
\hline Kadar air (\%) & 9,01 & 13,43 & 13,84 & Max 16\% \\
Kadar abu (\%) & $27,02^{\mathrm{c}}$ & $13,42^{\mathrm{a}}$ & $20,3^{\mathrm{b}}$ & Max 3.25\% \\
Kadar lemak (\%) & 6,5 & 6,74 & 5,77 & Max 5\% \\
Kadar protein (\%) & 51,67 & 65,43 & 59,05 & Min 50\% \\
Kadar karbohidrat by & 5,80 & 0,98 & 1,04 & - \\
difference(\%) & & & & $4-6$ \\
\hline pH & 4.76 & 4.0 & 3.56 & \\
\hline
\end{tabular}

Keterangan: Superskrip yang berbeda menujukkan perlakuan berbeda nyata $(\mathrm{P}<0,05)$.

\section{Karakteristik Kimiawi Gelatin}

Sifat kimia gelatin tulang itik yang diuji diantaranya kadar air, kadar abu, kadar lemak, kadar protein, kadar karbohidrat by difference dan $\mathrm{pH}$. Hasil pengujian disajikan pada Tabel 1. Air merupakan salah satu penentu kualitas gelatin. Kandungan air dapat mempengaruhi warna, rasa, dan masa simpan bahan. Rata-rata persen kadar air dari setiap perlakuan berturut-turut yaitu $9.01 \%$, $13.43 \%$, dan $13.84 \%$. Semakin tingi konsentrasi $\mathrm{HCl}$ yang digunakan maka kadar air akan semakin meningkat meskipun perbedaan konsentrasi $\mathrm{HCl}$ memberikan pengaruh yang tidak beda nyata $(\mathrm{P}>0.05)$. Semua perlakuan masih memenuhi syarat maksimal kadar air sesuai dengan standar SNI 06-3735-1995 yaitu sebesar 16\%. Semakin rendah kadar air yang dihasilkan maka masa simpan gelatin semakin meningkat, demikian juga sebaliknya. Jannah et al (2013) menyatakan semakin tinggi konsentrasi asam dalam proses demineralisasi maka kadar air yang dihasilkan juga akan semakin tinggi. Hal ini disebabkan karena asam kuat memiliki kemampuan yang lebih besar dalam menghidrolisis kolagen menjadi peptida gelatin yang lebih pendek. Peptida ini bersifat higroskopis (mudah menyerap air) sehingga kadar air gelatin juga akan semakin meningkat.

Abu merupakan komponen mineral yang terdapat di dalam tulang. Secara umum, mineral pada tulang didominasi oleh kalsium, fosfor, dan magnesium. Kadar abu gelatin tulang itik secara berturut-turut yaitu $27.02 \%, 13.42 \%$, dan $20.3 \%$. Perbedaan konsentrasi $\mathrm{HCl}$ yang digunakan memberikan pengaruh yang berbeda nyata $(\mathrm{P}<0.05)$. Kadar abu gelatin hasil penelitian jauh melebihi batas maksimal dari standar SNI 06-3735-1995 yaitu maksimum 3.25\%. Kadar abu yang tinggi mengindikasikan bahwa di dalam gelatin masih banyak terdapat komponen mineral. Nurilmala et al (2006) menyatakan kadar abu dalam gelatin bisa menjadi parameter keberhasilan proses ekstraksi. Semakin tinggi kadar abu maka proses ekstraksi yang digunakan belum optimal karena masih tersisa banyak residu mineral. Gelatin yang baik memiliki residu abu yang rendah dan berwarna cerah. Jannah et al (2013) melaporkan gelatin tulang ayam kampung dan broiler memiliki kadar abu yang tinggi. Hal ini diduga karena tulang unggas bersifat mudah rapuh dibandingkan tulang mamalia sehingga ketika tulang direndam dalam $\mathrm{NaOH}$ dan $\mathrm{HCl}$ akan pecah dan menyebabkan komponen mineral ikut terekstrak dalam aquades.

Lemak merupakan komponen yang secara umum tidak dapat larut di dalam air. Kadar lemak juga sebagai penentu kualitas gelatin meskipun bukan parameter utama. Kadar lemak gelatin yang diekstrak menggunakan $\mathrm{HCl}$ berturut-turut yaitu $6.5 \%$, $6.74 \%$, dan $5.77 \%$. Perbedaan konsentrasi $\mathrm{HCl}$ memberikan pengaruh yang tidak beda nyata $(\mathrm{P}>0.05)$. Kadar lemak gelatin tulang itik masih diatas batas maksimal yang ditetapkan oleh SNI 06-3735-1995 yaitu 5\%. 
Kadar lemak yang tinggi diduga karena memang karakter dasar dari itik adalah memiliki lemak yang tinggi. Damayanti (2006) menyatakan kandungan lemak pada daging dan kulit itik berturut-turut yaitu $8.47 \%$ dan 52.67\%. Zulfikar (2014) dalam penelitiannya melaporkan gelatin yang diekstrak dari tulang ayam kampung dan broiler memiliki kadar lemak berkisar $2.26 \%$ dan $2.0 \%$. Secara umum, golongan unggas yang memiliki lemak paling tinggi adalah itik. Hal inilah yang menyebabkan gelatin yang diekstrak dari tulang itik memiliki kadar lemak lebih tinggi dibandingkan tulang ayam.

Protein merupakan unsur terpenting dalam pembentukan gelatin. Gelatin terdiri dari minimal $50 \%$ protein. Gelatin mengandung semua jenis asam amino kecuali triptofan dan sistein. Kadar protein yang diekstrak dari tulang itik berturut-turut sebesar 51.67\%, 65.43\%, dan 59.05\%. perbedaan konsentrasi $\mathrm{HCl}$ memberikan pengaruh yang tidak berbeda nyata $(\mathrm{P}>0.05)$. Kadar protein semua perlakuan telah memenuhi syarat minimal berdasarkan standar SNI 06-3735-1995 yaitu 50\%. Kadar protein tertinggi terdapat pada perlakuan $\mathrm{HCl}$ konsentrasi 5\%. Jannah et.al (2013) melaporkan gelatin yang diekstrak dari tulang ayam menggunakan asam asetat memiliki kadar protein sebesar $86 \%$.

Protein kolagen terikat kuat pada jaringan ketika tulang masih utuh. Proses pretreatment menyebabkan kolagen mulai terlepas dari jaringan secara perlahan-lahan. Proses ekstraksi menyebabkan kolagen mengalami denaturasi yaitu struktur tersiernya terbuka (unfolding) sehingga protein kompleks kolagen berubah menjadi gelatin karena proses pemanasan. Proses ini bersifat irreversible, artinya ketika kolagen sudah menjadi gelatin, maka tidak bisa lagi kembali menjadi kolagen (Nurilmala et al, 2006). Batas maksimal suhu untuk ekstraksi gelatin adalah $90^{\circ} \mathrm{C}$, jika melebihi batas ini maka kolagen akan lebih terdenaturasi menjadi peptida sederhana dan tidak bisa dijadikan gelatin. Kombinasi suhu dan konsentrasi asam yang tepat mampu menghasilkan gelatin dengan kualitas bagus. Gelatin dengan kadar protein yang tinggi, memiliki sifat mudah larut dalam air, memiliki viskositas dan kekenyalan yang baik sehingga mudah diaplikasikan ke dalam produk pangan (Jannah et al, 2013).

Faktor-faktor yang mempengaruhi tingginya kadar protein dalam gelatin adalah sumber bahan baku dan metode ekstraksi. Gelatin yang dihasilkan dari hewan muda cenderung mudah diekstrak dan memiliki kandungan protein yang tinggi.Jaringan tulang hewan muda umumnya tidak terlalu keras. Semakin tua usia hewan, maka tulang semakin keras karena mineral penyusun tulang semakin padat. Hal ini menyebabkan proses ekstraksi cenderung lebih sulit dan kadar abunya tinggi.Metode ekstraksi juga mempengaruhi kadar protein. Metode ekstraksi asam cenderung menghasilkan gelatin dengan protein lebih tinggi dibandingkan basa terlebih lagi metode enzimatis.Akan tetapi, metode ini cenderung memiliki rendemen yang rendah (Nurilmala et al, 2006).

Karbohidrat merupakan senyawa organik kompleks yang tersusun dari monomer-monomer berupa monosakarida. Karbohidrat dalam penelitian ini dianalisis dengan metode by difference. Metode by difference merupakan metode menghitung jumlah karbohidrat dengan cara $100 \%$ dikurangi komponen yang lain yaitu air, abu, lemak, dan protein. Akurasi dari metode ini tidak tinggi. Rata-rata karbohidrat dari perlakuan berturut-turut adalah $5.80 \%$; $0.98 \%$; dan $1.04 \%$. Karbohidrat bukan merupakan parameter penting dalam gelatin melainkan hanya sebagai data pendukung. Parameter terpenting dalam gelatin adalah protein, air, dan abu.

$\mathrm{pH}$ menunjukan derajat keasaman atau kebasaaan suatu bahan. Nilai pH suatu bahan sangat dipengaruhi oleh jumlah asam yang terkandung didalamnya. Semakin tinggi jumlah asam $\left(\mathrm{H}^{+}\right)$maka $\mathrm{pH}$ semakin menurun. Demikian juga sebaliknya. Ratarata $\mathrm{pH}$ gelatin tulang itik yang diekstrak menggunakan $\mathrm{HCl}$ berturut-turut adalah 4.76; 4.0; dan 3.56. Perbedaan konsentrasi 
asam tidak memberikan pengaruh yang berbeda nyata antar perlakuan. Secara umum, pH gelatin masih memenuhi standar dari GMIA yaitu 3.8-5.5 dan SNI yaitu antara 4-6 kecuali perlakuan konsentrasi $\mathrm{HCl}$ $7.5 \%$. $\mathrm{HCl}$ merupakan asam kuat yang mampu mendegradasi tulang menjadi gelatin. Asam kuat seperti $\mathrm{HCl}$ dan asam sulfat sering digunakan untuk mengekstrak gelatin baik dari tulang maupun kulit. Huda (2013) menyatakan bahwa gelatin yang diekstrak menggunakan asam dalam waktu yang lama memiliki $\mathrm{pH}$ yang cenderung lebih rendah. Nurilmala et al, (2006) menambahkan penggunaan asam kuat dapat meninggalkan residu pada tulang sehingga $\mathrm{pH}$ menurun.

\section{Perlakuan Terbaik}

Perlakuan terbaik diambil dari perlakuan dengan jumlah protein dan rendemen tertinggi, dengan parameter lain yang masih memenuhi standar dari SNI. Perlakuan terbaik terdapat pada konsentrasi $\mathrm{HCl} 5 \%$ dengan kadar protein $65.43 \%$ dan rendemen $6.24 \%$. Perlakuan ini selanjutnya diuji warnanya menggunakan color reader dan gugus fungsionalnya menggunakan instrumen Fourier Transform Infra Red (FTIR).Pengujian warna memberikan hasil berupa nilai L, a, dan b. Nilai L menyatakan kecerahan (lightness) dengan nilai 0 (hitam) 100 (putih).Nilai a menunjukan redness atau merah hijau dengan nilai jika a+ maka menuju merah dan jika a- menuju hijau. Nilai b menunjukan yellowness atau kuningbiru dengan nilai jika b+ maka menuju kuning dan b- menuju biru.

Derajat warna sampel gelatin tulang itik yaitu $\mathrm{L}=30.35$; $\mathrm{a}=-0.46$; dan $\mathrm{b}=3.51$. Gelatin tulang itik cenderung berwarna kuning menuju coklat muda. Menurut standar SNI, gelatin memiliki warna kuning merah menuju coklat dengan intensitas antara 30-70.Warna gelatin tulang itik masih memenuhi standar, yaitu tidak terlalu putih dan tidak terlalu hitam. Buckle et al.(1987) menyatakan proses pengeringan menyebabkan perubahan warna pada produk pangan. Hal ini dikarenakan terjadi reaksi pencoklatan nonenzimatis yaitu reaksi maillard. Semakin lama proses pemanasan, maka semakin hitam warna produk yang dihasilkan. Rahmawati dan Pranoto (2016) menambahkan warna gelatin dipengaruhi oleh warna bahan dasar dan proses ekstraksi. Gelatin hitam biasanya dhasilkan dari sumber bahan yang juga lebih gelap.

Analisis gugus fungsional bertujuan untuk mengetahui pola sebaran ikatan molekul dalam sampel gelatin. Gelatin memiliki serapan gelombang yang khas dan mudah diketahui dari pola sebaran spektranya. Pola spektra FTIR gelatin tulang itik dapat dilihat pada Gambar 3 dan jenis ikatannya disajikan pada Tabel 2.

Tabel 2. Karakteristik gugus fungsi gelatin tulang itik

\begin{tabular}{|c|c|c|c|c|}
\hline \multirow[b]{2}{*}{ Regional } & \multicolumn{2}{|c|}{ Bilangan Gelombang (v) } & \multirow[b]{2}{*}{ Gugus Fungsi } & \multirow[b]{2}{*}{ Referensi } \\
\hline & Tulang itik $^{\mathrm{a}}$ & Kaki ayam ${ }^{b}$ & & \\
\hline Amida A & 3308 & 3399 & $N$-H stretching & Wang et al (2008) \\
\hline Amida B & 2922 & 2923 & $\begin{array}{l}\mathrm{CH}_{2} \text { stretching } \\
\text { asimetris }\end{array}$ & Coates $(2000)$ \\
\hline Amida 1 & 1645 & 1652 & $C=O$ stretching & Singh et al (2011) \\
\hline \multirow[t]{2}{*}{ Amida II } & 1539 & 1539 & $\begin{array}{c}C-N \text { stretching } \\
\text { dan } N-H \text { bending }\end{array}$ & Duan et al (2009) \\
\hline & 1457 & - & $\begin{array}{c}C-N \text { stretching } \\
\text { dan } N-H \text { bending }\end{array}$ & Kong dan Yu (2007) \\
\hline \multirow[t]{2}{*}{ Amida III } & 1336 & - & $\begin{array}{l}N-H \text { bending dan } \\
C-H \text { stretching }\end{array}$ & Woo et al (2008) \\
\hline & 1240 & 1241 & $\begin{array}{l}N-H \text { bending dan } \\
C-H \text { stretching }\end{array}$ & Woo et al (2008) \\
\hline
\end{tabular}

Keterangan : ${ }^{\mathrm{a}}$ (data penelitian), ${ }^{\mathrm{b}}$ (Almeida et al 2012). 


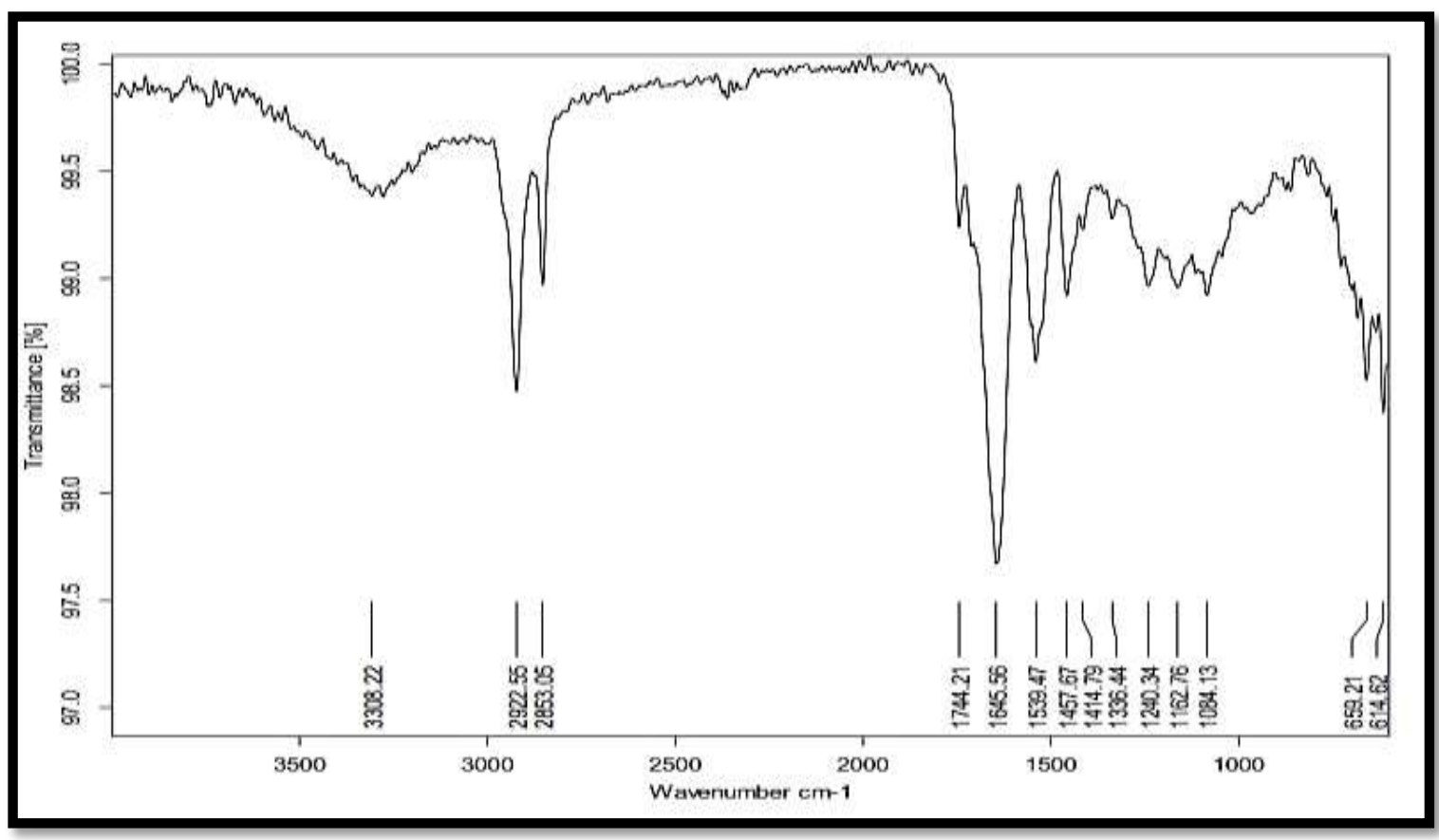

Gambar 3. Pola serapan gugus fungsi gelatin tulang itik

Gelatin tulang itik memiliki serapan pada wilayah amida $\mathrm{A}$, amida $\mathrm{B}$, amida $\mathrm{I}$, amida II, dan amida III. Pola serapan ini mirip dengan beberapa penelitian tentang gelatin seperti yang dilaporkan Almeida et al (2012). Tabel 7 menunjukkan amida A terdapat pada bilangan gelombang (v) 3308 $\mathrm{cm}^{-1}$. Menurut Wang et al (2008), amida A berhubungan dengan frekuensi $\mathrm{N}-\mathrm{H}$ stretching. Vibrasi $\mathrm{N}-\mathrm{H}$ stretching bebas terjadi pada kisaran $3400-3440 \mathrm{~cm}^{-1}$. Duan et al (2009) menyebutkan bahwa ketika gugus $\mathrm{N}-\mathrm{H}$ dari peptida mengandung ikatan hidrogen, posisinya dapat bergeser ke frekuensi yang lebih rendah yaitu sekitar $3300 \mathrm{~cm}^{-1}$. Amida B terdapat pada bilangan gelombang $2922 \mathrm{~cm}^{-1}$. Menurut Coates (2000) wilayah serapan pada bilangan gelombang 2935-2915 $\mathrm{cm}^{-1}$ menunjukan ikatan methylene $\mathrm{C}$ - $\mathrm{H}$ stretching asimetris.

Amida I gelatin tulang itik ditemukan pada bilangan gelombang $1645 \mathrm{~cm}^{-1}$.Singh et al (2011) menyatakan bahwa puncak amida I berada pada kisaran bilangan gelombang 1600-1700 $\mathrm{cm}^{-1}$. Puncak tersebut menunjukan adanya vibrasi $C=O$ stretching disepanjang polypeptide backbone, sekaligus merupakan pertanda dari struktur sekunder peptida. Menurut Prystupa dan Donald, (1996) amida I merupakan faktor terpenting dalam memahami struktur sekunder dari molekul protein.Bilangan gelombang pada sekitar $1660 \mathrm{~cm}^{-1}$ telah ditetapkan sebagai ikatan silang intermolekul. Amida II terdapat pada bilangan gelombang $1457 \mathrm{~cm}^{-1}$ dan $1539 \mathrm{~cm}^{-1}$. Menurut Kong dan Yu (2007), serapan amida II yang berada pada kisaran 1450-1575 $\mathrm{cm}^{-1}$ menunjukan adanya $C-N$ stretching dan $\mathrm{N}-\mathrm{H}$ bending. Gugus fungsi yang terakhir adalah amida III dengan serapan (v) $1240 \mathrm{~cm}^{-1}$ dan $1336 \mathrm{~cm}^{-1}$. Hasil penelitian ini sesuai dengan penelitian yang dilakukan Woo et al (2008) yang menunjukkan bahwa amida III memiliki serapan antara 1200-1400 $\mathrm{cm}^{-1}$. Puncak pada $1240 \mathrm{~cm}^{-1}$ dan $1336 \mathrm{~cm}^{-1}$ menunjukan adanya $\mathrm{N}-\mathrm{H}$ bending dan $\mathrm{C}-\mathrm{H}$ stretching.

Amida I, II, dan III berkaitan dengan derajat order molekul dan struktur helix dari gelatin yang dihasilkan dari $C=O$ stretching, $\mathrm{N}-\mathrm{H}$ bending, dan $\mathrm{C}-\mathrm{H}$ stretching (Muyonga et al., 2004). Selain menghasilkan 5 amida, gelatin tulang itik juga menghasilkan serapan dengan bilangan gelombang lebih rendah yaitu $1162 \mathrm{~cm}^{-1}$ dan $1084 \mathrm{~cm}^{-1}$. Menurut Coates (2000), spektra infra merah pada wilayah tersebut mengindikasikan adanya $C$ $O$ stretching dan $C-H$ bending.

Secara umum, gelatin yang diekstrak dari tulang itik menggunakan pelarut $\mathrm{HCl}$ 
dengan konsentrasi 5\% memiliki sifat, bentuk dan warna yang mirip dengan gelatin yang diekstrak dari sumber lain seperti kaki dan kulit ayam, tulang dan kulit sapi, dan juga komersial. Gelatin tulang itik memiliki pola spektra FTIR yang sama seperti standar dan memenuhi kriteria sebagai biomaterial berbahan dasar protein. Gelatin ini juga telah memenuhi persyaratan SNI kecuali kadar abu yang masih tinggi. Gelatin tulang itik dapat dijadikan sebagai alternatif sumber gelatin. Eksplorasi gelatin dari berbagai sumber telah dilakukan dan dilaporkan dalam 2 dekade terakhir, diantaranya dari sumber unggas, hewan laut (seafood), serangga, dan yang terbaru adalah dari mikroorganisme. Akan tetapi, eksplorasi ini kebanyakan belum sampai pada tahap produksi secara masal dan kontinu.Penelitian dasar ini dapat menjadi landasan dalam penelitian lebih lanjut. Di masa depan, gelatin tulang itik diharapkan mampu memenuhi kebutuhan gelatin yang terus meningkat seiring dengan perkembangan teknologi.

\section{KESIMPULAN}

Gelatin yang diekstrak dari tulang itik menggunakan larutan $\mathrm{HCl} 5 \%$ memberikan hasil yang terbaik dan memiliki karakteristik yang mirip dengan gelatin komersial. Gelatin ini bisa dijadikan sebagai alternatif sumber gelatin. Saran untuk penelitian selanjutnya yaitu perlu dilakukan kembali optimasi proses ekstraksi dan analisis sifat fisik gelatin untuk lebih memperkaya informasi yang diberikan.

\section{UCAPAN TERIMA KASIH}

Ucapan terima kasih disampaikan kepada Kementerian Riset Teknologi dan Pendidikan Tinggi melalui skema DIPA Politeknik Negeri Banyuwangi 2018 atas dana yang telah diberikan.

\section{DAFTAR PUSTAKA}

Almeida, P. F., S.C.S. Lannes., F.A. Calarge., T.M.B. Farias., J.C.C. Samtana. 2012.
FTIR characterization of gelatin from chicken feet. Journal of chemical engineering. 6: 1029-1032.

Buckle, K.A., Edward R.A., Fleet G.H. \& Wotton M. 1987. Food Science. Jakarta: UI-Press.

Coates, J. 2000. Interpretation of infrared spectra. A practical approach. Di dalam meyer R. A. Editor. Encyclopedia of analytical chemistry. Chichester: John Wiley \& Sons Ltd.

Damayanti, A. P. 2006. Kandungan protein, lemak, daging dan kulit itik, entog, dan mandalung umur 8 minggu.Jurnal Ilmu-Ilmu Pertanian. 13(3), 103-107.

Duan, R., Zhang J., Du X., Yao X., Konno K. 2009. Properties of collagen from skin, scale, and bone of carp (Cyprinus carpio). Food Chem 112, 702-6

Gelatin Manufacturer Association of Asia Pacific. 2007. Gelatin. Gelatin Food Science. 2004. Gelatin. http://www.gelatin.co.za/gltn1.[24 Februari2018]. 22:36 PM.

Gelatin Manufacturers Institute of America. 2012. Gelatin Handbook. New York (US): GEMIAnc.

Huda, N., E. K. Seow., M. N. Normawati., N. M. Aisyah. 2013. Preliminary study on physicochemical properties of duck feet collagen. International Journal of Poultry Science 12 (10): 615-621.

Jannah, A., Maunatin, A., Windayanti, A., Findianti, Y., dan Mufidah Z. 2013. Isolasi dan karakterisasi gelatin dari tulang ayam dengan metode asam. Jurnal Alchemy. 2 (3) 184-189

Kong,J., S. Yu. 2007. Fourier transform infrared spectroscopic analysis of protein secondary structures. Acta bioch bioch sin 39(8):549-559 
Mariod, A.A. 2013. Insect oil protein: Biochemistry, food and other uses: Review. Journal Agricultur Sciences. 14(9B) 78-80.

Miskah, S,. Ramadianti, I.M., dan Hanif, A.F. 2010. Pengaruh konsentrasi $\mathrm{CH} 3 \mathrm{COOH}$ dan HCL sebagai pelarut dan waktu perendaman pada pembuatan gelatin berbahan baku tulang atau kulit kaki ayam. Jurnal Teknik Kimia. 17(1) 1-6

Muyonga, J.H., Cole C.G.B., Doudu K.G. 2004. Fourier transform infrared (FTIR) spectroscopic study of acid soluble collagen and gelatin from skins and bones of young and adult nile perch (Lates niloticus). Food chemistry 86:325-332.

Nurilmala, M., M. Wahyuni., H. Wiratmaja. 2006. Perbaikan nilai tambah tulang ikan tuna menjadi gelatin serta analisis fisika-kimia. Buletin Teknologi Hasil Perikanan. Vol IX No.2 22-33.

Prystupa, D.A., A.M. Donald. 1996. Infrared study of gelatin conformations in the gel and sol states. Polymer gels and networks 4(2),87-110

Rahmawati, H. and Y. Pranoto. 2016. Physicochemical properties of gelatin from fresh and dry swamp ell and catfish skin. Fish Scientiae. 2(3), 1830.

Sari, D. K. 2017. Produksi gelatin halal dari kulit kaki ayam dengan penghilangan lemak berbeda dan aplikasinya pada es krim.[Tesis]. Sekolah Pasca Sarjana Institut Pertanian Bogor. Bogor.

Singh, P., S. benjakul., S.Maqsood., H. Kishimura. 2011. Isolation and characterization of collagen extracted from the skin of striped catfish (Pangasianodon Hypophthalmus). Food chemistry 124 (2011) 97-105

Standardisasi Nasional Indonesia. 1995. SNI 06-3735-1995. Mutu dan Cara Uji Gelatin.Standardisasi Nasional Indonesia. Jakarta.

Ulfa, M., W. Trisunaryati., II. Falah., I. Kartini. 2015. Characterization of gelatins from cow bone for carbon synthesis.IOSR Journal of Applied Chemistry. Vol 8, Ver II: 57063.

Wang, L., Yang B., Du X., Yang Y., Liu J. 2008. Optimization of conditions for extraction of acid-soluble collagen from grass carp (Ctenopharyngodon idella) by response surface methodology. Innov.Food Sci Emerg Technol 9, 604-7

Woo,J.W., S. Yu., S. Cho., Y.B. Lee., S.B. Kim. 2008. Extraction optimization and properties of collagen from yellowfin tuna (Thunnus albacores) dorsal skin. Food hydrocolloids. 22(5), 879-887

Zulfikar, A.S. Babji., W.M. Wan Aida. 2014. Penilaian kualitas fisika dan kimia gelatin ekstrak dari kaki ayam tua. Jurnal Peternakan. 11(1), 37-42. 